\title{
The right to a self-determined death as expression of the right to freedom of personal development: The German Constitutional Court takes a clear stand on assisted suicide
}

\author{
Ruth Horn
}

Correspondence to Dr Ruth Horn, The Ethox Centre, Wellcome Centre for Ethics and Humanities, Nuffield Department of Population Health, University of Oxford University, Oxford OX1 2JD, UK; ruth.horn@ethox.ox.ac.uk

\section{ABSTRACT}

On 26 February 2020, the German Constitutional Court rejected a law from 2015 that prohibited any form of 'business-like' assisted suicide as unconstitutional. The landmark ruling of the highest federal court emphasised the high priority given to the rights of autonomy and free personal development, both of which constitute the principle of human dignity, the first principle of the German constitution. The ruling echoes particularities of post-war Germany's end-of-life debate focusing on patient self-determination while rejecting any discussion of active assistance to die through a lethal injection administered by a doctor. This brief report discusses the ruling in the light of the broader sociopolitical and historical context of the German end-of-life debate.

On 26 February 2020, the German Constitutional Court ruled that

[t]he right to a self-determined death ${ }^{\mathrm{i}}$ involves the liberty to take one's own life. The individual's decision to end his/her own existence according to his/her understanding of quality of life and meaning of his/her own existence ought initially to be respected by the State and society as the act of autonomous self-determination. ${ }^{1}$

\section{'BUSINESS-LIKE' ASSISTED SUICIDE}

This landmark decision rejects the much-debated paragraph 217 of the criminal code (Strafgesetzbuch, StGB), which was enacted in 2015 to prohibit 'any business-like suicide assistance', as unconstitutional. The denotation of 'business-like' (geschäftsmäßig) not only referred to a commercial offer but also to any potentially recurring suicide assistance that might be provided by a doctor, nurse, relative or member of a right-to-die organisation. The Act to Criminalise Business-Like Assisted Suicide, adopted by the German Bundestag (Parliament) in 2015, aimed at addressing a grey zone in legislation. While the law associates active assistance to die (aktive Sterbehilfe), that is, an act where the doctor injects a lethal substance, with homicide $(\$ 212 ; 216$

${ }^{\mathrm{i}}$ The right to self-determination is defined as an expression of the general right of privacy which is not regulated by the fundamental law (Grundgesetz, $G G$ ) but by current jurisprudence and derives from the right of dignity (Art. $1 \mathrm{GG}$ ) and the right to freedom of personal development (Art. 2 GG).
StGB), suicide is not a criminal offence in Germany. Consequently, suicide assistance remains exempt from punishment. A person providing another person with a lethal drug could however be found guilty of an offence under the law on drugs, and a doctor providing suicide assistance could be sued for medical negligence ( $\$ 323$ c StGB). In 1984, a somewhat ambiguous ruling confirmed a doctor's duty to resuscitate a patient who has attempted suicide, while, at the same time, stating that medical negligence is not proven where resuscitation leads to permanent damage and the patient's wish to die can be proven. ${ }^{2}$ ii

Because of this grey zone in law, a number of attempts have been made in the past to establish organised, that is, business-like assisted suicide in Germany. In 2005, the Swiss right-to-die organisation Dignitas opened a branch in Hannover. ${ }^{3}$ Dignitas Germany does not deliver lethal substances to patients but facilitates contact with the Swiss organisation. In 2008, the former judiciary senator of Hamburg, Roger Kusch, publicly stated that he aided an elderly woman to commit suicide and offered this service on his website. Inspired by the American doctor Jack Kevorkian who invented a suicide machine in 1991, Kusch had developed a similar device that he offered for sale on his website. ${ }^{4}$ Finally, in 2014, the President of the Protestant Church publically declared that he would assist his wife who suffered from cancer if she wanted to commit suicide. In response, the minister of health at the time, Herman Groehe, called for a generalised prohibition of any kind of assisted suicide. $^{5}$

In the same year, 2014, four different draft acts on assisted suicide, which varied with regard to the types of assistance considered and its permissibility, were presented to and debated by the Bundestag. Following on from this, in 2015, the Bundestag adopted the Act to Criminalise BusinessLike Assisted Suicide ( $\$ 217$ StGB). The new paragraph 217 prohibiting any form of business-like suicide assistance was heavily criticised as 'unethical' and 'unconstitutional'. 6

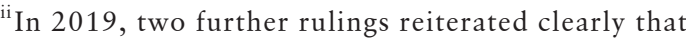
no medical negligence is provided even where the doctor assists a patient to commit suicide. ${ }^{3} \mathrm{BGH}$, 07.05.2019 - 5 StR 132/18, 5 StR 393/18 (2019). 


\section{THE SCOPE OF THE RIGHT TO SELF-DETERMINATION AT THE END OF LIFE}

A narrow reading of paragraph 217 suggested that putting higher, potentially lethal doses of medication at someone's disposal, or accepting a patient's wish to withdraw life-sustaining treatment, could become punishable under the new law. Many lawyers and doctors were concerned that ethically and socially accepted standards in medical practice (eg, adequate pain control and withdrawing treatment) could be seen as illegal and that the right to self-determination would be violated. ${ }^{7}$ This sits uncomfortably with a country that, since the Nuremberg trials, emphasises patient self-determination and respect for patient autonomy. ${ }^{8} \mathrm{An}$ analysis of the German end-of-life debate has shown that despite the strong emphasis on patient self-determination, active euthanasia involving a lethal injection, however, has always remained a taboo in post-war Germany. ${ }^{9}$ In the rare cases where death is seen as the last resort response to extreme pain and suffering, it appears that, in Germany, the public discussion focuses instead on assisted suicide. Assisted suicide enables the patient to preserve, until the end, control over interventions executed on his or her body, without delegating this control to another person. ${ }^{9}$ For many years, public opinion polls have been showing the strong support for assisted suicide among the general population as well as among doctors. ${ }^{10} 11$

Against this background, it is not surprising that the Court overturned the ban on assisted suicide by emphasising that $\$ 217$ limits the scope of assisted suicide to such an extent that the individual has de facto no space to exercise their constitutionally protected liberty. ${ }^{1}$ The Court accentuates the importance of the rights of autonomy and free personal development, both of which constitute the principle of human dignity, the first principle of the German constitution:

The autonomous determination of [the ending of] one's own life is the direct expression of the idea of free personal development that is intrinsic to human dignity [...]. The person committing suicide who acts based on his/her free will [...] gives up his/her life as an autonomous person and according to his/her own objectives. Consequently, human dignity is not the limit of a person's selfdetermination but its foundation: The person is recognised as responsible personality, as subject, [and] his/her individual value and right for respect is protected, only when he/she can determine his/her own existence according to his/her own, self-imposed standards. ${ }^{1}$

The high priority given to respecting autonomy and free personal development inevitably points to the influence of a Kantian tradition according to which the autonomy of the individual's will is the fundamental principle of all moral laws and the basis of human dignity. This tradition is embodied in the German constitution and echoed in the present ruling. Furthermore, the emphasis on autonomy and self-determination brings to mind the influence of the recent German history, that is to say the medical experiments and the euthanasia practices committed by the Nazis on a captive and non-consenting population, which resulted in the ethical principles fixed in the Nuremberg Code from $1947 .^{1}$

\section{THE NEED TO PROTECT AUTONOMY}

As much as the recent ruling praises self-determination and free personal development at the end of life, and takes a clear stand in favour of assisted suicide, it does not provide clear guidance on how to regulate assisted suicide. The Court, however, states that it is necessary for the legislator to protect the autonomous character of suicide by providing a regulatory framework.

The rejection of the ban of 'any form of business-like assisted suicide' raises ethical questions where such assistance involves commercial interests or leads to uncontrolled provision. ${ }^{12}$ In the case of commercialised suicide assistance in the private sector, it could be difficult to control and document who takes up such assistance and under what circumstances. For example, incompetent patients or patients who experience social pressure could request suicide assistance, which questions the autonomous character of the suicide. Furthermore, the commercial and uncontrolled availability of suicide assistance could take advantage of patients' vulnerability without investigating alternative means to address physical or psychological suffering. ${ }^{12}$

Therefore, for assisted suicide to remain an autonomous and deliberate act, the Court in this case emphasises the importance of a legal framework requiring the following: strict documentation of each case, an evaluation of the seriousness and durability of the request, an evaluation of alternative pain management, comprehensive counselling, prohibition of any form of social pressure and the need to reform the law on drugs to provide legal protection to those providing assisted suicide. The detailed formulation of such a framework will be the task of policymakers, legislators, politicians, doctors, patients and the broader society over the coming years. The theoretical ethical foundations for this have been laid by this ruling.

Contributors RH is the sole author of this paper.

Funding The author is based at the Wellcome Centre for Ethics and Humanities and the Ethox Centre which are both supported by a Wellcome Centre Grant (203132/Z/16/Z).

Competing interests None declared.

Patient consent for publication Not required.

Provenance and peer review Not commissioned; internally peer reviewed.

ORCID iD

Ruth Horn http://orcid.org/0000-0002-5714-3905

\section{REFERENCES}

1 Latour B, Woolgar S. The social construction of facts. Princeton University Press: Princeton, NJ, 1986

2 BGH. 04.07.1984 - 3 StR 96/84 1984

3 Lipp V, Simon A. Beihilfe zum Suizid: keine ärztliche Aufgabe. Deutsches Ärzteblatt 2011;108(5):A212-6.

4 Sterbehilfe. Gericht entscheidet über Polizeiverfügung gegen Kusch. Spiegel online 2008.

5 Gröhe will jede organisierte Sterbehilfe verbieten. die Zeit. 201426.72014.

6 Ou T, Simon A, Ostgathe C. Verbot Der geschäftsmäßigen Förderung Der Selbsttötung. Balanceakt in der Palliativmedizin Dtsch Arztb/ 2017;114:A302-7.

7 Hilgendorf E. Gesetz Zur geschäftsmäßigen Sterbehilfe: Eine norm für die Wissenschaft. legal tribute online, abrufbar unter, 2015. Available: https://www Ito de/recht/hinter gruende/h/gesetzgebung-sterbehilfe-tatbestandsmerkmale-analyse

8 Horn R. "Why Should I Question a Patient's Wish?" A Comparative Study on Physicians' Perspectives on Their Duties to Respect Advance Directives. Eur J Health Law 2017;24(5):523-40.

9 Horn R. Euthanasia and end-of-life practices in France and Germany. A comparative study. Med Health Care Philos 2013;16(2):197-209.

10 Ärztlich begleiteter Suizid und aktive Sterbehilfe aus Sicht der deutschen Arzteschaft [Internet]. Institut fuer Demoskopie Allensbach, 2010. Available: https://www. bundesaerztekammer.de/fileadmin/user_upload/downloads/Sterbehilfe1.pdf [Accessed 4 Mar 2020].

11 Mehrheit befürwortet ärztliche Sterbehilfe [Internet].. Report Mainz 'Sterbehilfe', KW 08/2020, 2019. Available: https://www.infratest-dimap.de/umfragen-analysen/ bundesweit/umfragen/aktuell/sterbehilfe/ [Accessed 4 Mar 2020].

12 Borasio GD, Jox R, Wiesing U. Selbstbestimmung Im Sterben-Fürsorge zum Leben: ein Gesetzesvorschlag Zur Regelung des assistierten Suizids: Kohlhammer Verlag 2014.

13 BGH. 07.05.2019 - 5 StR 132/18, 5 StR 393/18 2019. 